\title{
SUBSTANCE ABUSE AT THE WORK PLACE: THE PROBLEM AND POSSIBLE SOLUTIONS
}

\section{Lobelo Mogorosi}

\section{INTRODUCTION}

Personal problems, including substance abuse, often impinge on employees' job performance and therefore productivity. This paper discusses substance abuse as an example of an employee problem at the workplace that can be addressed through services such as employee assistance programmes (EAPs). The use and abuse of substances occur for a number of reasons, including misguided ones, such as a person trying to "forget problems" at home, socially or at work. In relation to work, the effects are enormous, such as employee absenteeism, workplace injuries, as well as damage to expensive workplace equipment and property. Aspects discussed in the paper include factors that help "enable" the abuse of such substances within the work environment, factors that indicate deteriorating employee work performance, as well as possible ways to deal with the problem at the workplace. The paper concludes with a discussion of possible workplace policies and programmatic solutions on how to deal with the problem.

\section{SUBSTANCE ABUSE AND RELATED PROBLEMS}

Substance abuse is about the bodily intake of drugs (legal or illegal) of natural or synthetic derivation that affect the central nervous system of the user. If used regularly, these drugs tend to be habit-forming and cause physical and psychological dependence in people. Discussing substance use and its abuses, Blume (1999:72) refers to the human fascination with, and use of, various kinds of "mind-altering techniques, including reduction of sensory input, repetitive dancing, sleep deprivation, fasting and prolonged meditation". The end result of this fascination with, and use of, these substances is usually devastating for the abusers and others along the way. The victims include the abuser (e.g. physical and psychological dependence, disciplinary action and job loss), the family (loss of income and shattered relations), the society (need to direct scarce resources to rehabilitation programmes) and the workplace (loss of productivity and work accidents). Substance abuse leads to addiction, and personal and social problems. According to Betancourt and Herrera (2006:17), alcohol is a leading substance of abuse in South Africa and because of the high levels of its consumption it becomes associated with "violence, crime and traffic-related trauma".

Regular intake of drugs may result in addiction. Rip (1978:86) defined drug addiction as "a state of periodic or chronic intoxication detrimental to the individual and to society, produced by the repeated consumption of a drug (natural or synthetic)". Characteristics of addiction include an overpowering desire and a compulsive need for the drug of choice, to obtain it by any means, a tendency to increase the dose, as well as a psychological and sometimes physical dependence on the effects of the drug. The South African National Council on Alcoholism and Drug Dependence (SANCA, 1993) defined an alcoholic as someone who cannot at all times control their drinking and who will encounter problems in other areas of life. These areas include psychological, spiritual and physical health, family, marriage and finances. Often a person with a substance abuse problem cannot or will not face the facts about their addiction. This denial will usually become entrenched as the addiction progresses, until the person hits "rock bottom". 
Instead of facing their problems, substance abusers often tend to justify them by adopting various defence mechanisms, which are ways and means to explain their situation. SANCA (2009) lists these defence mechanisms as follows:

- Denial: the insistence that substance use is not a problem and adoption of flat rejection of reality which may be too painful to face;

- Blaming or projection: the use of particular substances is not denied. But the cause of indulgence is related to someone or something else, such as a difficult spouse, children, bosses, retrenchment or the difficulties of life;

- Rationalisation: the use of particular substances is not denied, but good excuses and explanations are given for continuing indulgence;

- Minimising: the abuser tends to be ashamed of own actions and behaviour, and therefore tries to manage continued actions and behaviours by reducing the intake of the substances of choice, but the intake of the substances continues; and

- Diversion: the abuser always tries to tactfully change the subject of discussion, diverting attention from anything that might be relevant to their problem and situation.

Table 1 presents types of substances and their general effects on abusers (Blume, 1999:73). Table 2 provides available historical data that demonstrate the levels of drug problems in South Africa from the mid-1990s to the early 2000s. The data show a selection of illegal drugs of choice in the form of the amounts seized. Three selected examples of substances that are mostly used in South Africa, namely, alcohol, dagga and Mandrax, are then briefly discussed.

TABLE 1

SUBSTANCES AND THEIR GENERAL EFFECT

\begin{tabular}{|l|l|l|}
\hline CATEGORY & \multicolumn{1}{|c|}{ EXAMPLES } & \multicolumn{1}{c|}{ GENERAL EFFECT } \\
\hline Alcohol & Beer, wines and spirits & $\begin{array}{l}\text { Impaired judgment and motor function, } \\
\text { and slow reflexes and somnolence }\end{array}$ \\
\hline Depressants & $\begin{array}{l}\text { Sleeping medicines, sedatives } \\
\text { and some tranquillisers }\end{array}$ & $\begin{array}{l}\text { Inattention, slowed reflexes and } \\
\text { drowsiness }\end{array}$ \\
\hline Opiates & $\begin{array}{l}\text { Heroine, morphine and some } \\
\text { pain medication }\end{array}$ & Loss of attention and "nodding" \\
\hline Stimulants & Cocaine and amphetamines & $\begin{array}{l}\text { Elevated mood, over-activity, rapid } \\
\text { heartbeat, tension and anxiety }\end{array}$ \\
\hline Cannabis & Marijuana & $\begin{array}{l}\text { Distorted time sense, impaired memory } \\
\text { and co-ordination }\end{array}$ \\
\hline Hallucinogens & LSD and PCP petrol and & $\begin{array}{l}\text { Inattention, sensory illusion, } \\
\text { disorientation, hallucination and } \\
\text { psychosis }\end{array}$ \\
\hline Inhalants & $\begin{array}{l}\text { Hydrocarbons, judgment and motor function, } \\
\text { dizziness and headaches }\end{array}$ \\
\hline Nolvents & $\begin{array}{l}\text { Initial stimulant and then depressant } \\
\text { effects }\end{array}$ \\
\hline
\end{tabular}


TABLE 2

A SELECTION OF DRUGS CONFISCATED BY THE SOUTH AFRICAN POLICE SERVICE (1995-98* AND 2000s**)

\begin{tabular}{|c|c|c|c|c|c|c|}
\hline DRUG & QUANTITY & 1995 & 1996 & 1997 & 1998 & $\begin{array}{c}* * 2000 \text { 's } \\
\text { (estimated amounts } \\
\text { used) }\end{array}$ \\
\hline Dagga & $\begin{array}{l}\text { Kilograms } \\
\text { (kg) }\end{array}$ & 192812 & 203354 & 171929 & 197116 & 40000 metric tons \\
\hline Cocaine & grains $(\mathrm{g})$ & 187615 & 106629 & 151000 & 636000 & 4.6 metric tons \\
\hline Hashish & grams (gm) & 7858 & 1065 & 2000 & 18000 & $\begin{array}{l}\text { Used by estimated } 9 \% \text { to } \\
11 \% \text { of drug patients in } \\
\text { Gauteng, Cape Town \& } \\
\text { Mpumalanga }\end{array}$ \\
\hline Heroin & grains $(\mathrm{g})$ & 5942 & 811 & 2000 & 5000 & \\
\hline LSD & Units & 4107 & 11804 & 2730 & 6426 & \\
\hline Mandrax & Tablets & 886846 & 432807 & 1629531 & 1307109 & \\
\hline Ecstasy & Units & N/A & 3138 & 118784 & 111733 & 2 metric tons \\
\hline Speed & Units & N/A & 128 & 283 & 527 & \\
\hline
\end{tabular}

* Data adopted from SA Institute of Race Relations Survey 1997/98 and 1999/2000 ** National Drug Master Plan (2006-2011)

\section{Alcohol abuse}

In South Africa the most widely used substance is alcohol. An estimated six billion litres of alcohol are consumed annually, making an annual average of 10 litres per adult. Extrapolating from the 1991 SANCA figure of R11.4 billion, approximately R15 billion were spent annually, on above-the-line liquor advertising in South Africa during the mid-1990s (SANCA, 1993; The Star, 3 September 1997). Current estimates for the last 10 years are that R47 billion is spent on alcohol and related marketing per annum ("A Drunken Nation", 2008). The National Drug Master Plan (2006-2011) shows that the problem of substance abuse continues, and that in the 2000s it was estimated that at least $7.5 \%$ to $31.5 \%$ of South Africans continue to have a drinking problem of some form.

\section{Dagga (Marijuana/Matekwane)}

The most widely used illegal drug in South Africa is dagga, which is a widely available indigenous plant. Abuse of this substance may lead to a variety of dependency problems (psychological, physical and tolerance). Table 2 shows that during the 2000s a large quantity of dagga was still being confiscated on the South African streets (National Drug Master Plan, 2006-2011). This is an indicator of the high level of a social problem affecting mostly young men. A considerable number of young men begin smoking dagga together with cigarettes during their high school days. This practice continues into young adulthood. The prevailing myths are that dagga is not as harmful as alcohol, that it heightens concentration and perception, enhances performance, including easing pressures of work (Johnson, 2007:20). The belief is that it calms the nerves, or in township language: "It gives one a 'plak' (courage)". 


\section{Mandrax}

After dagga, Mandrax was the second most popular illegal drug in South Africa from the 1980s to the 2000s. The use of Mandrax tablets can lead to the development of psychological and physical dependency and also tolerance to its effects. The substance has a "slowing down" effect on the central nervous system, producing feelings of relaxation, confidence and euphoria. Its adverse effects are reactions of severe headaches, nausea and skin rash (De Miranda, 1987; SANCA, 1993). By the late 1990s and 2000s data show that some 1.3 million tablets were confiscated by law-enforcement authorities (SAIRR, 1999 /2000).

\section{WORKPLACE FACTORS THAT “ENABLE” SUBSTANCE ABUSE}

All kinds of workplaces are at risk of creating a problem of employee substance abuse. This is because many workplace factors may unintentionally enable, induce or provide a "supportive" atmosphere for employee substance abuse. Employing organisations, employee service providing professionals and labour policy makers need to be aware of these factors. Writers such as Backer and O'Hara (1991), Babedi, Makeketlane, Mapolisa, Moema, Gumede \& Motswenyane (1988) and Muloiwa (2008) identify many factors enabling substance abuse in the workplace.

\section{Work environment and occupational stress}

Muloiwa (2008:7-8) states that a number of adverse work environmental factors can make even some of the best jobs stressful, which may contribute to employee problems such as substance abuse. These factors could include uncomfortable work settings, lack of safety, inadequate physical or financial resources, poor supervision and problems with co-workers, low pay, poor training and job preparation, job insecurity and lack of opportunities for career advancement.

Stress refers to a condition resulting from a perceived discrepancy, whether real or not, between the demands of a situation and the resources of the person's biological, psychological or social systems (Sarafino, 1990:74). Muloiwa (2008:4) defines occupational stress as poor mental wellbeing directly related to unpleasant work conditions, resulting from high work demand and a low amount of control over the situation. Occupational stress contributes towards employee absenteeism, diminished performance, negativity and cynicism, a decline in commitment and creativity, decreased ability to concentrate, and less interaction with other employees. Stressed workers can also develop a range of symptoms including insomnia, headaches, fatigue, anxiety, irritability and depression. Some of these employees may resort to substance abuse to cope with their situations (Muloiwa, 2008:7-8).

\section{Workplace culture}

Employers need to make their stance clear on substance abuse, to address the unofficial practices that may be taking place within their organisations. Officially a blind eye may be turned to some employees' practices. At worst, some of these practices may have come to be accepted in some workplaces, for instance, drinking during work breaks (the so-called "liquid lunches") in the locker rooms, or for that matter during working hours (Backer \& O'Hara, 1991). At times the nature of the work itself may place very high demands on the workers, so

that they may be tempted to use alcohol or other drugs to absorb the pressure. The demand, for example, to maintain the required levels of productivity and constant deadlines, working nightshifts, long shifts, constant long-distance driving, job complexities and role conflicts may all play an important part in particular employees' behaviours. 
The National Drug Master Plan (2006-2011:21) lists some of the occupational groups as being at "risk" of abuse of substances. These include: artists, musicians, medical personnel, farm workers and transport industry workers, especially long-distance truck drivers. The nature of the environment plays part in terms of work demands and pressures, while also part of the problem could be culture of such occupations.

Employees may be aware that some amongst them are abusing drugs. A blind eye may have been turned, with no repercussions. For that matter, those identified in the past may have been leniently treated. This may have been in spite of the organisation's "noise" made around the subject.

\section{Denial of the existence of the problem}

For a variety of reasons organisations may simply turn a blind eye to the use or abuse of substances, as long as they are perceived as not affecting the "work". The general attitude is that substance abuse is an individual employee's problem. The view is that the publicity that may come as a result of the problem may not be "good for the business". This may particularly be so for small organisations, especially those that perhaps rely on small markets, which may react negatively to the publicity (e.g. loss of customers). Publicising the presence of a problem, therefore, is perceived to threaten the image or the very survival of reporting organisations (Backer \& O'Hara, 1991).

Some employers may not believe that there may be a problem worth investigating. The attitude is one of denial, where employers may say something like: "Our employees don't do that, we know them. They know it is against company policy, and for that matter, they know the consequences: expulsion". This may be the position until, for example, an employee loses a limb or his/her life, as a result of their own or someone else's substance abuse while at work.

\section{Availability of the substances in the environment}

This factor has more to do with the organisation's geographical location and the availability of addictive substances in and around the workplace. The location of the workplace and its area of operation are important. Is the workplace, for example, located in or near a neighbourhood area with stores that sell alcoholic substances?

An experience that the author knows of is that of a public relations officer who was constantly intoxicated, even at work. His job included receiving and entertaining many visitors to the institution (i.e. prospective donors, academics and government officials), who came on a daily basis. On arrival or during various functions these visitors would be offered all sorts of beverages such as tea, soft drinks and beer. The public relations officer would take the advantage of the work situation, drink all sorts of alcoholic beverages and in the process lose control over his drinking. His work performance was adversely affected.

Backer and O'Hara (1991) also give examples of employees in the pharmaceutical environment, where medication drugs are widely available. This is where health professionals such as doctors, nurses and other general medical workers are found. There could be abuse problems if drug and medicine control procedures are not properly adhered to. The question here becomes: to what degree is the work environment to blame? The lethal combination is both the poor administrative controls and the poor will power on the part of the individual professional. 


\section{Social control and peer pressure}

There is also an element of the work environment and atmosphere which fosters no freedom of independent individual behaviour. Another situation is the pressure of constant employee supervision. Employees with a "need to belong" and get accepted may succumb to pressures by doing what they think is right in terms of that particular social or work group's norms (Johnson, 2007:7). Unfortunately the co-workers' activities may include drinking and the use of other substance during breaks, as well as before or after work. The attitude and thinking is that: "If you do not do as we do here, you belong to the other side." This is important in small groups where everyone who belongs is expected to comply with group norms.

\section{Alienation and dissatisfaction}

Some work environments isolate workers from their social support networks when these are needed. This is experienced during times of stress and dissatisfaction related to problems such as: work overload and job complexities, unpleasant work atmosphere, poor pay, feelings of powerlessness and other personal issues in the workers' private lives. Such employees may hang onto anything they can. This may include, unfortunately, being tempted to use alcohol and other substances.

Babedi et al. (1988) aptly describe the dilemma facing the mineworkers (the "men between two worlds") in the context of South Africa during the 1980s as a succinct example of employee alienation, which may ultimately tempt them to resort to substance abuse to cope with the pressures. The majority of these mineworkers are African men from a traditional rural life, who come to enlist for jobs at the urban-based mines. Historically these work settings belittled and ridiculed these men and regarded the miners' lifestyles as primitive and uncivilised and treated them accordingly. This often leads to the mineworkers feeling alienated and becoming socially dysfunctional - a man who has lost self-confidence, selfrespect and initiative. "Physically he is on the mines but his heart is with the family he left way back home. In consequence many resort to aggression and other related negative behaviour as methods in trying to negotiate the new and complex life" (Babedi et al., 1988:6).

This factor has more to do with the organisation's geographical location and the availability of addictive substances, in and around the workplace. The location of the workplace and its area of operation are important. Is it located, for example, in an urban or rural setting, and in what type of neighbourhood?

\section{INDICATORS OF DETERIORATING EMPLOYEE WORK PERFORMANCE}

How can work organisations detect and evaluate that they have substance abuse problems within the ranks of their employees? Carver and Poone (1989:190) put it clearly, stating that "it is important to acknowledge that there are no specific or behavioural signs and symptoms, or laboratory or clinical tests that are one hundred percent sensitive and reliable in the identification of a substance abuse problem". A combination of elements may be used to indicate the possibility and potential existence of the problem. The work supervisor or manager closest to the workers can play an important role in detecting work performance problems. It is not a case of one or two problems, but a combination of a number of these elements that can give an indication of potential existence of a problem.

Elements of employee deteriorating work performance include, but are not restricted to, the employee behavioural problems shown in Table 3 (Carver \& Poone, 1989; Foote et al., 1984; 
Kurzman, 1992; Mogorosi, 1997; Roche Diagnostics, 2000; Roman, 1990; Sonnenstuhl \& Trice, 1990).

\section{TABLE 3}

\section{ELEMENTS AND SIGNS OF EMPLOYEE DETERIORATING WORK PERFORMANCE}

\begin{tabular}{|l|l|}
\hline \multicolumn{1}{|c|}{ CATEGORY } & SIGNS OF DETERIORATING WORK PERFORMANCE \\
\hline $\begin{array}{l}\text { Poor work } \\
\text { performance }\end{array}$ & $\begin{array}{l}\text { Frequent mistakes, carelessness, irregular quality of work, } \\
\text { poor concentration, frequent signs of tiredness and difficulty } \\
\text { with work instructions. Signs of stress. Poor judgment and } \\
\text { costly errors. Reduced productivity and uneven work quality. }\end{array}$ \\
\hline $\begin{array}{l}\text { Inattentiveness and } \\
\text { absence }\end{array}$ & $\begin{array}{l}\text { Frequent work mistakes and tardiness, timing of the mistakes } \\
\text { (e.g. mornings, after vacations and Mondays), and extended } \\
\text { work breaks. Absenteeism and frequent lateness. Frequent } \\
\text { illness and use of sick leave. }\end{array}$ \\
\hline $\begin{array}{l}\text { Behaviour and } \\
\text { physical } \\
\text { appearance }\end{array}$ & $\begin{array}{l}\text { Intra-personal changes (e.g., frequent memory lapses, poor } \\
\text { concentration and general irritability). Evidence of substance } \\
\text { abuse and intoxication. Problems with supervisors and co- } \\
\text { workers, loss of enthusiasm for work, apathy and sloppy work, } \\
\text { poor appearance and personal hygiene, watery and bloodshot } \\
\text { eyes. Changes and problems in personality, and peculiar } \\
\text { conduct. }\end{array}$ \\
\hline $\begin{array}{l}\text { Health and } \\
\text { workplace safety }\end{array}$ & $\begin{array}{l}\text { Indifference towards safety regulations, frequent work accidents, } \\
\text { carelessness with dangerous machinery and equipment. DWI } \\
\text { (driving while intoxicated) accusations and charges. }\end{array}$ \\
\hline $\begin{array}{l}\text { Personal and } \\
\text { relationship problems }\end{array}$ & $\begin{array}{l}\text { Indication of personal and relationship problems (family, } \\
\text { social, financial, social and legal). }\end{array}$ \\
\hline
\end{tabular}

Even though they need to know about various indicators of deteriorating employee work performance, it is essential to emphasise that the only job of a supervisor or manager is to supervise employees' work, as they are not professionally qualified to detect and make a clinical diagnosis of employee substance abuse. After detecting the possible presence of a problem that is affecting the employee's work performance, supervisors and managers can then make appropriate referrals for some organisational intervention.

\section{POSSIBLE SOLUTIONS TO EMPLOYEE SUBSTANCE ABUSE}

As stated in the introduction, employees' substance abuse often impinges on their job performance. Instead of dealing with the problem when it first appears, some work organisations may adopt the response of ignorance or denial of the existence of the problem. Thinking and caring work organisations need to step in to offer help, when work and other personal problems affect employees and their work performance.

Venter (2004:272-273) suggests that unless the possible consequences of employee's substance abuse action are sufficiently serious (e.g. a bus drivers' drunkenness at work as compared to pool typist's), severe sanctions such as dismissals for the first offence will not be appropriate. He states that measures such as a warning (verbal or written) could be the appropriate first step. Hard-line disciplining, suspension and even terminating the services of 
employees may not be the best solutions or even feasible at times because of "costs" involved. Punitive measures may only result in the affected employees going underground, hiding problems, some becoming less trusting and disloyal, as well as possible employee or union litigation against their employers for one or other reason. Possible organisational "costs" of not handling problems properly here refer to possibilities of:

- losing experienced and trained employees;

- needing to train their replacements;

- disruption of work process due to the loss of some employees;

- effect on work team morale and problems of lower productivity; and

- feelings of job insecurity, seeing the dismissals of valued co-workers (Mogorosi, 1997:58$61)$.

Successful implementation of suggested policies and approaches, in a given context, depends on the applicable socio-economic factors. These factors include societal values and the quality of available social and kinship support networks, the economic climate, current social policy, service delivery systems and labour relations.

Suggested policies and approaches need to reflect that employees will be helped to work through their problems when both the employees and employers agree that some action will be necessary. It should be noted here, however, that employees are expected to look for solutions on their own and rely on their resources so as to maintain their independence. When employees' resources are exhausted and the problems are beyond their control, outside help from others, including the employers, may be called upon. For this approach to succeed, the goals dealing with employee substance abuse problems should include provision of:

- the due process through organisational policies for affected employees;

- counselling and other services by professionals rather than by work supervisors, managers and unions representatives; and

- all forms of assistance to help retain employees in whom work organisations have a commitment, in return of their loyalty.

Again, when help is provided through work organisations' help channels such as referral processes or a dedicated employee assistance programme (EAP), confidentiality and current or future position of affected employees should not jeopardised. This policy principle needs to be clearly spelt out by organisational policies as well as EAP administrators to the clients and to all other employees in their work organisations.

\section{Legal provisions}

The Code of Good Practice in the Labour Relations Act (No. 66 of 1995) provides for employers to institute disciplinary procedures for infractions of rules governing conduct of employees. Employee misconduct includes behaviours such as wilful damage to property and endangering of the safety of others, insubordination, assault and fighting, as well as intoxication on duty and drug use. Possible disciplinary measures include warnings, suspensions, transfers, demotion and dismissals (Theme 3: Dismissal on account of misconduct, 2006:53; Venter, 2004:244). As shown in Table 3, these types of misconduct reflect some of the general characteristics of individuals with substance abuse problems. 
Fair disciplinary procedures for dealing with employee misconduct are required to ensure proper labour relations. The Code of Good Practice in the Labour Relations Act (1995) and the Guide to Labour Relations Act, 1995 (2002:60-61) state that:

- employers should adopt disciplinary rules that set out how employees must behave at work;

- rules must be clear and employees should be informed about them;

- an effort must be made to correct employees' behaviours by means of graded disciplinary actions, whereby minor infractions and initial problems should be handled through providing advice and correction;

- alcoholism and drug abuse are to be included in the classification of "incapacity: ill-health or injury";

- to deal with alcoholism and drug abuse, employers are expected to consider counselling and rehabilitation as appropriate remedies; and

- even "if there are very good substantive reasons for a dismissal, an employer must follow a fair procedure before dismissing an employee. This requires the employer to conduct an investigation into the alleged misconduct" (Guide to Labour Relations Act, 1995 (2002:60).

\section{Organisational policy approaches}

Whatever policies are devised to deal with substance abuse, they should have as their primary focus "employee job performance". These policies need to include two factors: encourage employees to seek professional help and spell out penalties for failure to comply with organisational regulations.

Should the work organisation have a dedicated programme that is set up to help with employee problems - such as an EAP - its staff should assist with training of both the managers and supervisors. If there is no workplace programme in place, arrangements can be made to get outside expertise on the subject matter. Part of the training needs to include both managers and supervisors so that they may "constructively confront" employees on the basis of poor work performance - rather than on any other basis. This is because managers and supervisors are not specifically trained or qualified to assess substance abuse.

Staudenmeier (1987) presents four types of policy approaches - specifically on alcohol - which could be used in combination with other solutions. These four approaches may serve as pointers for the broad policy guidelines for employing organisations.

- "Drinking on the job": In this policy approach, employers acknowledge that drinking is an integral part of life. Here alcoholic beverages are allowed and provided at the workplace on particular occasions such as celebrations of events, victories and holidays.

- "Dry on the job": This policy approach seeks to totally remove alcoholic beverages from the workplace. Employees are encouraged to abstain from using these substances at the workplace. Most employers follow this kind of policy, as they do not necessarily have to do anything outside of publicising "prohibition".

- "Employee rehabilitation": This policy calls for employees to abstain from alcohol use, both at the workplace and away from it. This approach encourages employees to seek rehabilitation. It seeks to inform employees about the dangers of the use of any alcoholic drinks and other substances to personal wellness, with special effect on own health, family and social life. It encourages employees to consider generally staying away from indulging themselves. 
- "Occupational alcoholism programmes": The focus of this policy approach is on helping to identify and rehabilitate employees who have substance abuse problems. This policy is best exemplified by the existence of a workplace programme that is dedicated to dealing with employee substance abuse problems.

\section{Organisational policy statement}

To deal effectively with an employee substance abuse problem, work organisations need to develop in-house guidelines in the form of a clear policy statement. Roche Diagnostics (2000:63) suggests that "anti-drug programmes in firms" should include five factors: (1) an anti-drug policy must be written in a clear and understandable language; (2) the need for work supervisors to undergo special training on the handling of employee substance abuse problems should be spelt out; (3) employees to be made aware of the seriousness of the organisational anti-drug policy; (4) organisational programmes to spell out recognition of employees problems and the need to help solve them, as well as the implementation of the helping processes; and (5) a provision for drug testing.

Furthermore, Loup (1994:19-23) suggests that at a minimum an organisational "drug-abuse policy" should contain the following elements:

- A position statement that reflects the company's view of drug abuse as a risk to security or safety, a liability to productivity, or a medical or personal problem;

- A statement documenting previous incidents and the company's desire to prevent such incidents in the future;

- A list of the company's responsibilities to its employees, and the department charged with these responsibilities;

- A list of employees' responsibilities or conditions of employment;

- Procedures the company will implement to achieve the goals of the policy; and

- The consequences of violating organisational policy, including testing positive for drugs or refusal to submit to testing.

\section{Organisational prevention and detection strategies}

To deal with some of the employee substance abuse problems a number of prevention and detection strategies are suggested to help work organisations (Axel, 1986; Backer \& O'Hara, 1991; Lyons, 1987; Myers, 1985; Roche Diagnostics, 2000). It has to be emphasised that those designated with the task need to be qualified officials. As appropriate to a setting, these strategies include:

- prospective pre-employment screening and background checks: this strategy involves a process of establishing and confirming information about prospective employees before they are hired. Information checks may include verification and confirmation of information supplied with previous employers, law-enforcement agencies and associates;

- employee searches and use of observations methods: this strategy is about establishing what may be going on within the workforce that may be unlawful. Methods used - within the law - include periodic bodily searches of employees, their effects and work stations to monitor possible possession of undesirable substances and involvement in unwelcome activities. Other strategies involve work organisations using electronic equipment and devices to record movement and activities of employees and others at worksites; and 
- periodic and random testing: this strategy involves use of methods and devices to monitor and test employees for the possible use of a variety of drugs. Methods used include breathalyser, urinalysis as well as a variety of other laboratory tests involving samples of saliva, hair or blood.

\section{Information giving and awareness campaigns}

At the very least a work organisation needs to bring to the attention of its employees the seriousness of its views on the subject. This could be in the form of a published policy statement, pre-employment discussions, informational leaflets, brochures and posters, educational videos and films (Mogorosi, 1997:58-61).

In their daily encounters with employees (individuals or groups) with a variety of presenting problems, EAP professionals may have to take those opportunities to provide information about the danger of not addressing personal problems such as substance abuse. Employees may need to be informed about general characteristics of troubled substance abusers, such as behaviour patterns, stages of regression into the problem, denial, co-dependence and the possible effect on their employment situation and family, as well as what is available in terms of services being offered by the organisational programme.

\section{Issue-focused education and training}

As appropriate and necessary, a work organisation can arrange information sessions and workshops for its managers, supervisors and employees on the subject matter. Such training needs to include discussions on issues such as:

- the meaning and implications of employee substance abuse;

- factors that contribute to employee substance abuse (as shown in Table 3, listed as "elements and signs of employee deteriorating work performance");

- organisational policies and procedures for handling problems and challenges of employee substance abuse;

- when and how to use "constructive confrontation" as an approach to dealing with the problem;

- referral processes for employees who need help; and

- available services and resources for referral and treatment (such as early identification, counselling for employees and families, in-patient and out-patient treatment and detoxification, as well as Alcohol Anonymous support groups) (Hanson, 1993:218-230).

EAP coordinators, human resource personnel and occupational nurses are suggested as appropriate professional staff to run such training and information sessions. Places that could be approached include the local and provincial Departments of Health and Social Development, health/medical institutions and practitioners, social workers, the Institute of People Management (IPM) and the South African National Council for Alcohol and Drug Dependence (SANCA).

\section{Development of open channels of communication}

Channels of communications are processes and routes put in place to pass on and receive information within an organisation. Elements of the process here involve the respect and recognition of the role of everyone involved. As Steinberg (1996:100) aptly puts it: "organisations are held together by communication". The better organisational members communicate, the better the organisation will operate. Open channels of communication are 
therefore crucial for the distribution and interpretation of information within an organisation. Again, the presence of a clear organisational hierarchy makes both downward and upward communication relatively easier.

Substance abusers are characterised by general behavioural patterns that include an inability to discuss personal problems, loss of interest in usual activities such as personal and work responsibilities, withdrawal from their own groups, loneliness, general life crises, as well as rebelliousness and violations of the law (Johnson, 2007). These characteristics make substance abusers to become "hard-to-reach". Work organisations therefore need to ensure that they develop and adopt ways that will enable them to quickly identify and help deal with employees' work and personal problems that interfere with their responsibilities. These ways need to ensure confidentiality, respect and personal development.

The route for the communication of information and discussions depends on the organisation. These routes are not mutually exclusive as organisations can use a combination of methods. To deal with work-related and employee personal challenges that impinge on their work, some organisations utilise the team briefing approach, where managers, supervisors and members of work teams meet regularly, for example, on weekly or monthly basis. Others utilise union representatives to communicate and to get feedback about any other matters. Another route of communication is the negotiation and dispute resolution process. The resolution process adheres to a framework that is agreed upon by management and employee representatives on labour disputes and any other cases of conflict resolution.

\section{Work environment and occupational stress management}

Muloiwa (2008:7) states that a number of adverse work environmental factors can make even some of the best jobs stressful, which may contribute to employee problems such as poor work performance and substance abuse. Stress is the result and response to pressure, which brings feelings of loss of control over one's environment and circumstances. Corey and Corey (1992:260) define stress as "the condition that exists when the environmental demand exceeds your personal capabilities for coping with the work situation". Stress may result in an imbalance of the body and mind that may lead to physical illness or mental breakdowns. The results of employee stress problems may be very costly for work organisations. Examples include: employee absenteeism due to ill health and mental breakdown; substance abuse in employees' mistaken efforts to thwart and/or sustain work pressure; high accident rates due to inability to cope with the pressure; and low morale, which may result in poor work performance.

It is the duty of the employer to make sure that occupational stress is addressed with immediate effect. Interventions at the work environment level should ideally focus on changing or improving the individual skills in coping with occupational stress as well as changes in the work environment itself. Within the work environment other important avenues for stress management include clear job descriptions, proper employee supervision, formal and informal colleague support, constant consultations, keeping work stimulating, where possible reducing the workload, as well as instituting flexible time schedule $\mathrm{s}$ and employee leave (Ross \& Deverell, 2004:309).

\section{The establishment of employee assistance programmes (EAPs)}

Employee assistance programmes are critical vehicles to help deal with the problem of employee substance abuse. These are intervention programmes designed to enhance employees' effectiveness through prevention, early identification and resolution of both work 
and personal problems that may adversely affect employees' job performance and their family social functioning. Sonnenstuhl and Trice (1990:1) see EAPs as job-based programmes operating within organisations "for the purpose of identifying troubled employees, motivating them to resolve their troubles, and providing access to counselling or treatment for those who need the services". In addition, the definition of EAP the Standards Committee of the Employee Assistance Programme Association - South Africa (EAPA-SA) focuses on the issue that such programmes revolve around identification and resolution of "productivity problems associated with employee impaired by personal concerns ..." (Standards Committee: EAPA-SA, 1999:5).

Historically, workplace programmes started in the United States (US) as occupational alcoholism programmes (OAPs) during the 1940s, concentrating on identifying employees suspected to be alcoholics and motivating them to join Alcoholics Anonymous (AA). Work supervisors were trained in techniques of placing alcoholic employees in "job jeopardy". This involved discussing the possibility of employees losing their jobs if they did not stop drinking, followed up with offers of mandatory supervisory referrals to the organisation's OAP, leading to possible referrals to detoxification and rehabilitation, all as alternatives to losing their jobs (Kurzman, 1992:78-88). US OAPs were mostly staffed by recovering alcoholics, who had been sober for some time. Most of the OAP staff had no formal professional training background. But as Kurzman (1992:80) observes, the situation inevitably became increasingly complicated:

"When the early OAP programmes found themselves dealing with a rapidly increasing number of clients with non-alcohol related personal and emotional problems, they discovered that their skills were becoming marginal to the organization's performance expectations."

To deal with the above complications, in the 1960s a new approach was put forward whereby, instead of training supervisors to recognise "alcoholism", the focus became "job performance" to identify employees with problems and the use of "constructive confrontation" strategies. This involved motivating substance-abusing employees to either change their behaviour or seek help (Sonnenstuhl, 1988:347-364).

In South Africa industrial nurses played a key role in encouraging many companies during the 1960s and 1970s to introduce some form of employee assistance. Pioneering work on employee substance abuse treatment, as a specific workplace challenge, began in the mining industry in the 1970s, where mining houses provided their own alcohol and psychiatric treatment facilities for their hostel-housed employees. These facilities were eventually broadened into fully-fledged assistance programmes by the early 1980s (Du Plessis, 1991; Mogorosi, 1997). Since the early 1980s SANCA has played a significant role in alerting work organisations about substance abuse. Through its Durban-based Information and Preventive Service office, it has assisted employers by training EAP coordinators and provided information on substance abuse and its effect at the workplace, helping "troubled employees" and with the establishment of programmes (Wilcocks \& Edmonds, 1992:65-77). A majority of responding programmes heads in the Mogorosi (1997) study indicated that the 1990s South African EAPs dealt with employee personal, health and work-related challenges (e.g. family, financial, HIV/AIDS, substance abuse, absenteeism and poor interpersonal relations), as well as addressing training needs. Subsequent studies by Ramokolo (2004), Chabeli (2006) and Khorommbi (2007) confirmed similar trends, where they established that EAPs deal with issues such as work relationship challenges, employee personal problems (e.g. marital, substance 
abuse and legal challenges), financial management difficulties, staff morale and productivity challenges, as well as HIV/AIDS. These programmes address such problems and challenges through counselling, referrals, campaigns and training.

For professional service provision within EAPs, Kurzman (1987) sees occupational social work playing a central role in service delivery in programmes for employees. He defines occupational social work as programmes and services "under the auspices of labor or management, that utilise professional social workers to serve members or employees and the legitimate social welfare needs of the labor or industrial organisation" (Kurzman, 1987:899). In addition, Smith and Gould (1993:12) describe employee assistance as the "best-known model of social work practice at the workplace". Akabas (1995) lists the tasks that occupational social workers are expected to perform within work-based programmes:

- Consultations and advocacy for employee needs and policy situations;

- Client assessment and intervention, using short-term and crisis intervention methodologies;

- Facilitation of negotiations and resolution of conflicts between employees and their supervisors and managers; and

- Referrals to and the development of relationships with community-based service-providing agencies.

In conclusion, Hanson (1993:222-230) suggests that EAP professional staff need to have a particular understanding to enable them to help employees with substance abuse problems. Such understanding has several dimensions:

- The success of their programmes and interventions lies in plans and strategies for early identification of employees and environmental challenges and problems;

- The need to offer help within professional boundaries of confidentiality and non-judgmental attitude;

- People seek help under a variety of circumstances; some employees may recognise that they have a problem, while some do not, and yet others may be in denial;

- When affected individuals come for help, they may be in different stages of the problem and addiction;

- Programme staff have to help affected employees understand the influence of their addiction problems on their work performance and possible fate of their work status;

- As substance abuse can have effects beyond the workplace, it may be necessary to extend help to significant others, such as spouses and children;

- Such employees may have to be referred to specialist professionals outside the work programme for treatment and further help; and

- EAP staff may have to work out some plan for reintegration into the workplace to help prevent relapse and support their recovery.

Each of the suggested solutions here has a bearing on important issues of fairness, avoidance of discrimination, individual rights, confidentiality and good working relationships. It is important, therefore, that whatever approach organisations finally adopt, they would need to comply with labour relations legislation, the Constitution and, more importantly, respect universal human rights. With the help of the services of employee assistance programmes, managers and supervisory staff would need to be made aware through training about the indicators of substance abuse problems and their impact at the workplace. 


\section{REFERENCES}

A DRUNKEN NATION. 2008. news24.com. August 26.

AKABAS, S.H. 1993. Introduction. In: KURZMAN, P.A. \& AKABAS, S.H. (eds) Work and well-being: the occupational social work advantage. Washington, DC: NASW Press. AKABAS, S.H. 1995. Occupational social work. In: Encyclopaedia of Social Work $\left(19^{\text {th }}\right.$ ed). Silver Springs, Maryland, USA: NASW Press.

ALCOHOL AND OTHER DRUG USE, ABUSE AND RELATED PROBLEMS. 1993. SANCA Fact Sheet. Johannesburg: SANCA Society.

AXEL, H. (ed) 1986. Corporate strategies for controlling substance abuse. New York: Conference Board, Inc.

BABEDI, N., MAKEKETlAnE, E., MAPOLISA, S., MOEMA, M., GUMEDE, D. \& MOTSWENYANE, B. 1988. Selected features of industrial social work practice with black mine workers on a gold mine. Social Work Practice, 6(1):2-9.

BACKER, T.E. \& O'HARA, K.B. 1991. Organizational change and drug-free workplace: template for success. New York: Quorum Books.

BALGOPAL, P.R. \& PATCHNER, M.A. 1988. Evaluating employee assistance programs: obstacles, issues and strategies. Employee Assistance Quarterly, 3(3/4):95-105.

BETANCOURT, O.A. \& HERRERA, M.M. 2006. Alcohol and drug problems and sexual and physical abuse at three urban high schools in Mthatha. South African Family Practice, 48(4):17-19.

BLUME, A. 1999. Employee substance abuse. Health Protection \& Promotion in the Workplace: Encyclopaedia of Occupational Health and Safety, 15:72-76.

CARVER, V. \& POONE, C. 1989. Women, work and wellness. Toronto, Canada: Addiction Research Foundation.

CHABELI, T.N. 2006. Perceptions of employees regarding the utilisation of in-house employee assistance programme model by the North West Department of Education Pretoria: University of Pretoria. (Unpublished MSD EAP Thesis)

COREY, G. \& COREY, M. 1992. Becoming a helper. Monterey, California: Brooks/Cole Publishers.

CORNEIL, D.W. 1987. Alcohol in employment settings: the results of the WHO/ILO international review. Employee Assistance Quarterly, 3(2):5-48.

DE MIRANDA, S. 1987. Drugs and drug abuse in Southern Africa. Pretoria: J.L Van Schaik (Pty) Ltd.

DU PLESSIS, A. 1991. A society in transition: EAP in South Africa. EAP Digest, 11(3):3566.

FOOTE, A., ERFURT, J.D., STRAUCH, P.A. \& GUZZARDO, T.L. 1984. Costeffectiveness of occupational employee assistance programs. Ann Arbor, Michigan, USA: Institute of Labor and Industrial Relations, University Of Michigan.

HANSON, M. 1993. Serving the substance abuser in the workplace. In: KURZMAN, P.A. \& AKABAS, S.H. (eds) Work and well-being: the occupational social advantage, Washington, D.C.: NASW Press. 
HOW TO DEAL WITH DRINKING AT WORK. 1993. The weekly mail, April 8-15. Johannesburg.

INSTITUTE OF RACE RELATIONS SURVEY (1997-1998). 1998. Johannesburg: South African Institute of Race Relations.

INSTITUTE OF RACE RELATIONS SURVEY (1998-1999). 1999. Johannesburg: South African Institute of Race Relations.

INSTITUTE OF RACE RELATIONS SURVEY (1999-2000). 2000. Johannesburg: South African Institute of Race Relations.

JENKINS, J.L. 1988. Health enhancement programs: balanced lifestyles, physical fitness, smoking cessation, stress management, and weight control. In: GOULD, G.M. \& SMITH, M.L. (ed) Social work in the workplace: practice and principles. New York: Springer Publishing Co.

JOHNSON, L. 2007. Program for anti-substance abuse and empowerment ( ${ }^{\text {rd }}$ ed). SANCA, World ORT Trust \& ORT South Africa.

KHOROMMBI, N.N. 2007. Evaluation of employee assistance programme in the Department of Public Works: Vhembe District. Polokwane: University of Limpopo. (Unpublished MA Thesis)

KNOW YOUR LRA: A GUIDE TO THE LABOUR RELATIONS ACT, 1995 (as amended). 2002. ( $2^{\text {nd }}$ ed). Department of Labour, Tshwane.

KURZMAN, P.A. 1992. Employee assistance program staffing: past, present and future. Employee Assistance Quarterly, 8(2):79-88.

KURZMAN, P.A. 1987. Industrial social work (occupational social work). In: Encyclopedia of Social Work $\left(18^{\text {th }}\right.$ ed). Silver Springs, Maryland, USA: NASW Press.

LABOUR RELATIONS ACT, No. 66 of 1995.

LEARNER SUPPORT PROGRAMME. 2009. SANCA Far North, Polokwane.

LOUP, S. 1994. Drugs and alcohol in the workplace. Employee Counseling Today, 6(5):1923.

MOGOROSI, L.D. 1997. Employee assistance at the workplace: the South African experiences and model. New York: Columbia University. (Unpublished Doctoral Dissertation)

MULOIWA, S.L. 2008. Mental health-dedicated nurses and handling of possible occupational stress. Thohoyandou: University of Venda. (Unpublished Mini Thesis)

MYERS, D.W. 1985. Employee problem prevention and counseling. Westport, Connecticut, USA: Quorum Books.

NATIONAL DRUG MASTER PLAN (2006-2011). 2006. Tshwane, National Department of Social Development.

RAMOKOLO, M.E. 2004. The exploration of the resistance of troubled employees to utilise the employee assistance programme at Aventis Pharma. Pretoria: University of Pretoria. (Unpublished MSD EAP Thesis)

RIP, C. 1978. Contemporary social pathology ( $2^{\text {nd }}$ ed). Pretoria: Academia.

ROCHE DIAGNOSTICS. 2000. Drug of abuse - misuse and detection. Mannheim, Switzerland: Roche Diagnostics GmbH. 
ROSS, E. \& DEVERELL, A. 2004. Psychosocial approaches to health, illness and disability: a reader for health care professions. Pretoria: Van Schaik Publishers.

ROMAN, P.M. 1990. Alcohol problem: intervention in the workplace, employee assistance programs and strategies. New York: Quorum Books.

SA AMONG THE HIGHEST ALCOHOL CONSUMING COUNTRIES. 1997. The Star, September 3. Johannesburg.

SANCA TRAINING MANUAL. 2009. Polokwane: SANCA Far North Society.

SARAFINO, E.P. 1990. Health psychology: biopsychosocial interaction $\left(2^{\text {nd }}\right.$ ed $)$. New York: John Wiley \& Sons, Inc.

SMITH, M.L. \& GOULD, G.M. 1993. A profession at the crossroads - present and future. In: KURZMAN, P.A. \& AKABAS, S.H. 1988. Work and well-being: the occupational social work advantage. Washington, D.C.: NASW Press.

SONNENSTUHL, W.J. 1988. Contrasting employee assistance, health promotion, and quality of work life programs and their effects on alcohol abuse and dependence. The Journal of Applied Behavioral Sciences, 24(4):347-364.

SONNENSTUHL, W.J. \& TRICE, H.M. 1990. Strategies for employee assistance programs: the crucial balance $\left(2^{\text {nd }}\right.$ ed). Ithaca, Cornell University, New York: ILR Press.

STANDARDS FOR EMPLOYEE ASSISTANCE PROGRAMMES IN SOUTH AFRICA. 1999. Standards committee of EAPA-SA.

STAUDENMEIER, W.J. (jr) 1989. Contrasting organizational responses to alcohol and illegal drug abuse among employees. Journal of Drug Issues, 19(4):451-471.

STEINBERG, S. 1996. Organizational communication. In: VAN RENSBURG, R.S. Introduction to communication. Kernwyn: Juta \& Co.

THEME 3: DISMISSAL ON ACCOUNT OF MISCONDUCT. 2006. Advanced course in labour law. Bloemfontein: University of the Free State.

VENTER, R. 2004. Labour relations in South Africa. Cape Town: Oxford University Press.

WILCOCKS, L. \& EDMONDS, L. 1992. Alcohol and drug abuse: treatment alternatives in South Africa. Employee Assistance Quarterly, 7(3):65-77.

Dr Lobelo Mogorosi, Department of Social Work, University of Venda, Thohoyandou, Limpopo Province, South Africa. 